\title{
Identification of SNP c.-22G $>A$ in the melanophilin gene from a dog with color dilution alopecia: case report
}

\author{
[Identificação do SNP c.-22G>A no gene da melanophilina em um cão com alopecia \\ por diluição da cor: relato de caso] \\ L.M. Santos ${ }^{1}$, N.B. Messas ${ }^{1}$, M.I.P. Palumbo ${ }^{2}$, L.A. Miyasato ${ }^{3}$, P.V. Leal ${ }^{4}$, \\ T.B. Martins ${ }^{2}$, C.A.N. Ramos ${ }^{2 *}$ \\ ${ }^{1}$ Residência - FAMEZ - Universidade Federal de Mato Grosso do Sul - Campo Grande, MS \\ ${ }^{2}$ FAMEZ - Universidade Federal de Mato Grosso do Sul - Campo Grande, MS \\ ${ }^{3}$ Aluno de graduação - FAMEZ - Universidade Federal de Mato Grosso do Sul - Campo Grande, MS \\ ${ }^{4}$ Aluno de pós-graduação - PPGCV-FAMEZ - Universidade Federal de Mato Grosso do Sul - Campo Grande, MS
}

\section{RESUMO}

Alopecia por diluição da cor é um defeito ectodérmico caracterizado por alopecia parcial, pelagem seca e sem brilho, escamação e pápulas em áreas com defeitos na melanização e na estrutura cortical dos pelos. Os animais acometidos têm grânulos de melanina grandes e com formato irregular nos ceratinócitos basais, nas células da matriz dos pelos e nas hastes pilosas. Não existe tratamento específico que altere a evolução da síndrome, mas, em alguns animais, podem ser benéficos banhos semanais com xampu de peróxido de benzoíla, para reduzir a formação de seborreia e infecções secundárias. Há evidências de que a condição em cães é causada por uma mutação de ponto no gene que codifica a proteína melanophilina. No presente estudo, é relatada a identificação da mutação SNP c.-22G>A no gene da melanophilina em um cão da raça Dachshund com evidências clínicas e histopatológicas de alopecia por diluição da cor.

Palavras-chave: genotipagem, dermatologia, doenças de pele, herança mendeliana

\begin{abstract}
Mutant color alopecia is an ectodermical defection of color dilution, characterized by partial alopecia, dry, shine-less hair, and peeling and papule. Melanization damages also occur on the cortical structure of the affected hair. The animals affected have big melanin grains with irregular shape on the basal keratinocytes, also on the hair matrix cells and rod. Therefore, there is not a specific treatment that makes any difference on the syndrome evolution. Although in some animals, it is possible to use weekly showers with benzyl peroxide to reduce seborrhea formation and secondary infections. There is evidence that the condition in dogs is caused by a single nucleotide polymorphism in the gene encoding the melanophilin protein. In the present study the identification of the SNP c.-22G>A in the melanophilin gene of a Dachshund breed dog with clinical and histopathologic evidence of color dilution alopecia is reported.
\end{abstract}

Keywords: genotyping, dermatology, skin diseases, mendelian inheritance

\section{INTRODUCTION}

Color dilution alopecia is an uncommon dermathological disease characterized by hair loss in colorful areas like black, brown, red and blue. It can be observed in many species such as dogs (Perego et al., 2009; Palumbo et al., 2012),

Recebido em 11 de janeiro de 2017

Aceito em 26 de abril de 2017

*Autor para correspondência (corresponding author)

E-mail: carlosanramos@yahoo.com.br cats (Ishida et al., 2006), cattle (Li et al., 2015), and other species. This phenotype is caused by a defective transport of melanosomes that leads to accumulation of large clumps of pigment within melanocytes (macromelanosomes) (Drogmuller et al., 2007). Sometimes it is accompanied by hair loss and recurrent skin inflammation in dilutely pigmented areas, so-called color dilution 
alopecia (CDA), color mutant alopecia (Kim et al., 2005) or black hair follicular dysplasia (BHFD) (von Bomhard et al., 2006).

CDA is inherited as a Mendelian autosomal recessive trait, that has been described in various dog breeds (Kim et al., 2005; Welle et al., 2009) with color-diluted coats (Gross et al., 2005). The condition in dogs has been associated to a single nucleotide polymorphism (SNP c.-22G>A) at the splice donor of exon 1 in the melanophilin gene (MLPH) (Drogemuller et al., 2007; Welle et al., 2009). The melanophilin protein along with MYO5A and RAB27A have been described as essential for distribution, transport and translocation of pigment granules (Barral and Seabra, 2004). Diagnosis is based on the clinical history, skin exams, histopathology and genetic analysis.

The aim of this study is to report a case of color dilution alopecia with detection of the SNP c. $-22 \mathrm{G}>\mathrm{A}$ in a Dachshund dog.

\section{CASE REPORT}

A 1-year-old male Dachshund dog was referred to the Veterinary Hospital of FAMEZ/UFMS in Campo Grande, state of Mato Grosso do Sul, Brazil, due to lameness of the right hind leg. On physical examination, there was increased sensitivity in the right hip region, hindering the movement of abduction. The owner also mentioned she had noticed progressive hair loss through the dog's body that started months before, but that was not of primary concern for her once the dog did not seem to be bothered. Clinically, there was generalized rarefaction of fur, poor hair quality (dry, opaque and brittle), and thin skin scabs, especially in coat color dilution areas. Other clinical and physical alterations were not observed.

Hair samples from alopecic areas were collected for direct examination and fungal culture, skin scraping was performed for mites' research, and skin biopsies were performed for histopathological purposes. A sample of heparinized blood was obtained for genetic analysis.

DNA extraction was performed from $350 \mu 1$ of blood using Easy DNA gDNA purification kit (Invitrogen). After extraction, the DNA samples were subjected to electrophoresis on $0.8 \%$ agarose gel and spectrophotometry at 260 and $280 \mathrm{~nm}$ in BioPhotometer Plus apparatus (Eppendorf) for assessing the integrity, concentration and purity, respectively. The presence of inhibitors in the extracted DNA samples was assessed by PCR for $\beta$-actin constitutive gene.

For the animal genotyping a $312 b p$ DNA fragment, comprising exon 1 region of the gene MLPH, was amplified by PCR. Amplification was performed with primers MLPH_157395_F (5 'CCTTCCTTCCCCTGTAGGAC 3') and MLPH_157706_R 'GCCTAAAATGAGCTCCCTGA 3') (Drogemuller et al., 2007), in a final volume of $25 \mu \mathrm{L}$ containing $12.5 \mu 1$ GoTaq $2 x$ Green Master Mix (Promega), $10 \mathrm{mM}$ of each primer, about $100 \eta \mathrm{g}$ of DNA and nuclease free water in sufficient quantity to complete the final reaction volume. The amplified fragments were visualized in UV transilluminator and Gel Doc XR photo documentation system (Bio-Rad) after electrophoresis on $1.5 \%$ agarose gel.

The amplified fragments were ligated to the plasmid $p$ Gem-T Easy (Promega) according to the manufacturer's recommendations, and then were inserted into Escherichia coli (Top 10) chemically competent. Bacteria were plated in Luria Bertani (LB) agar containing ampicillin $(100 \mathrm{ug} / \mathrm{ml})$ and incubated at $37^{\circ} \mathrm{C}$ for 18 hours. The bacterial colonies containing the insert were selected by PCR using the same primer set described previously (MLPH_157395_F and MLPH_157706_R).

Among the positive clones, one was randomly selected and cultured in LB broth containing ampicillin $(100 \mu \mathrm{g} / \mathrm{ml})$ at $37^{\circ} \mathrm{C}$ under constant agitation in shaker incubator during 12 hours. The bacteria were recovered by centrifugation $(10,000 \mathrm{xg}$ for $5 \mathrm{~min})$ and subjected to plasmid DNA extraction with the aid of GenCatch Plus Plasmid DNA Miniprep kit (Life Science Epoch) according to the manufacturer's recommendations. The plasmids were sequenced in both directions in the ABI 3130 automated sequencer using BigDye Terminator v3.1 (Applied Biosystems) and primers M13.

The DNA sequences were initially evaluated and consensus sequences were generated with the aid 
of the DNASTAR package (Lasergene). The consensus sequence was deposited in Genbank NCBI under accession number KU577346.

At direct exam, melanin clusters were seen at the hair shafts cortex and medulla, and cuticles presenting defects and fractures were also observed. No fungus or mite were recovered. Histopathological findings in hematoxylin and eosin stained slides were mostly severe, and consisted of lack of most of hair shafts and distortion of the remaining ones; follicles with irregular contour and dilated by keratin; clumped melanin accumulation in hair bulbs hair shafts, around the follicular bulb and in the epidermis; and epidermal pigmentary incontinence. Multiple small foci of periadnexal lymphoplasmacytic inflammatory infiltrate were also observed.

Through homology search with the aid of the Blastn program, it was possible to identify three polymorphisms (SNPs) throughout the $312 \mathrm{bp}$ fragment obtained in this study, using as reference the sequence available in GenBank (accession number BN000728). The identified SNPs occur at the following positions: 157471 $(\mathrm{G}>\mathrm{A})$ and $157486(\mathrm{C}>\mathrm{A})$, both in noncoding region of splice donor of exon 1 of MLPH gene.

\section{DISCUSSION AND CONCLUSION}

CDA is a hereditary disorder of dilute colored dogs, characterized by development of alopecia in dilute coat color areas. It has been observed in different dog breeds (Welle et al., 2009), including Dachshund (blue and brown), in which it was observed change in color of coat for a faded or dead leaf coloring, even during the puppy phase (Gross et al., 2005). Initially the affected animals exhibit gradual emergence of a poor coat, dull, dry, brittle, and broken hairs, developing partial alopecia that can lead to total alopecia of diluted coat (Harvey and McKeever, 2004).

Affected animals show large melanin granules and irregularly shaped in the basal keratinocytes, in the cells of the matrix and the hair shafts. It has been suggested that the hair matrix cells are affected by the cytotoxic effects of melanin precursors which result in the interruption of growth and, finally, on follicular dysplasia. It is believed that the extensive clumping of melanin in the hair, associated to distortion of cortical and cuticular structures lead to fragility and breakage of the hair shafts at these sites (Harvey and McKeever, 2004). In the present report, similar signals were observed at histopathological analysis of the affected animal.

In a study conducted by Drogmuller et al. (2007), a SNP (G>A) located in the 5'-UTR region of exon 1 of the MLPH gene (genomic position 157471, reference sequence BN000728) was indicated as the possible responsible for color dilution phenotype in dogs. Subsequently, in a study using 935 dogs of different breeds, of which 112 showing coat color dilution phenotype, perfect association between the phenotypic trait and SNP c.-22G>A was observed (Welle et al., 2009).

In the present study, we found a SNP G>A (genotype AA, evidenced by the analysis of the electropherogram), in the same genomic position previously described by Drogmuller et al. (2007), on DNA sequence from CDA affected animal (Figure 1A). The SNP was located in a region of DNA sequence with a high Phred quality score (Figure 1B). Therefore, the present result reinforces the previous scientific evidence that a mutation $\mathrm{G}>\mathrm{A}$ at 5 '-UTR region of exon 1 of the MLPH gene is responsible for the coat color dilution phenotype in dogs. In addition, since the phenotype predisposes dogs to the development of alopecia and other skin diseases in the color dilute areas, the identification of animals carrying the recessive allele, as well as the removal of affected dogs of reproduction are measures needed to prevent the spread of phenotype.

The dog of the present study was treated for the primary problem (lameness of the right hind leg), and the owner received information about the etiology and care needed with skin disease. Because of the genetic component of this condition, further breeding of the dam and male that resulted in this dog was discouraged. 
A

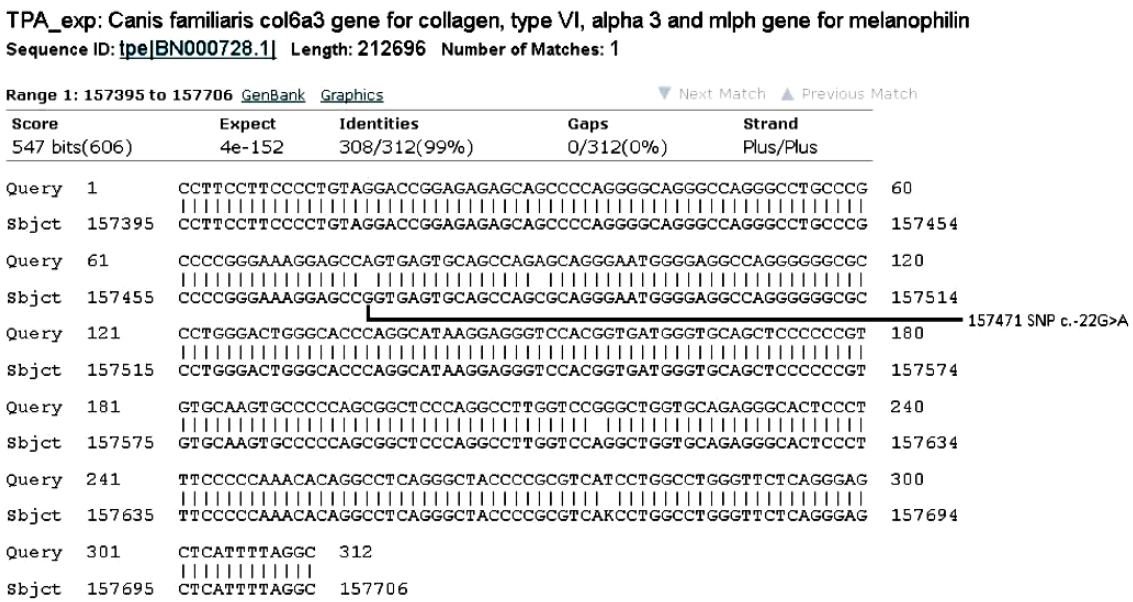

B

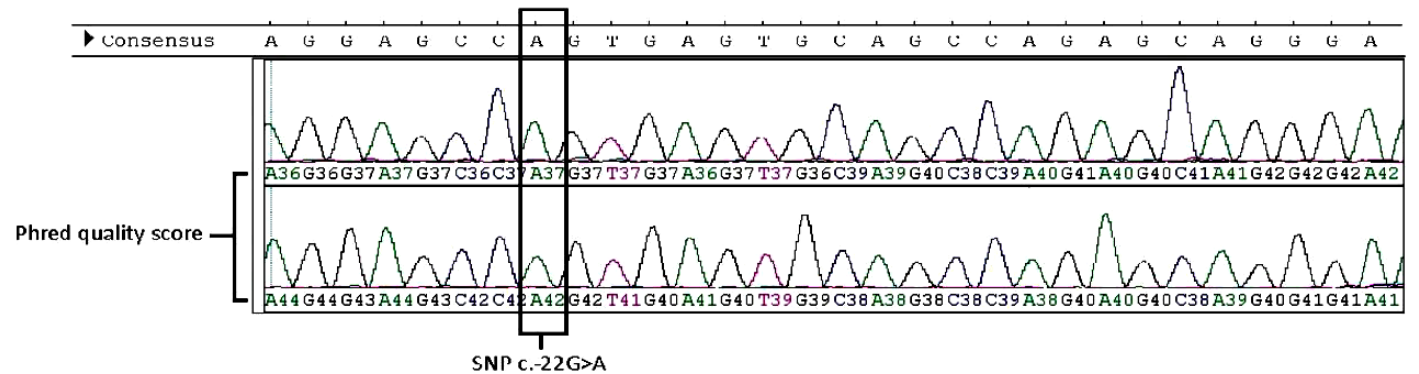

Figure 1. Identification of SNP c.-22G>A in melanophilin gene of a dog with color dilution alopecia. (A) Alignment using the Blastn program (NCBI) between the DNA fragment of the affected animal and the reference sequence deposited at Genbank (arrow indicates the position of the SNP). (B) Electropherogram of the melanophilin gene fragment containing the SNP c.-22G>A.

\section{REFERENCES}

BARRAL, D.C.; SEABRA, M.C. The melanosome as a model to study organelle motility in mammals. Pigment Cell Res., v.17, p.111-118, 2004.

DRÖGEMÜLLER, C; PHILIPP, U.; HAASE, B. et al. A noncoding melanophilin gene (MLPH) SNP at the splice donor of exon 1 represents a candidate causal mutation for coat color dilution in dogs. J. Hered., v.98, p.468473, 2007.

GROSS, T.L.; IHRKE, P.J.; WALDER, E.J. et al. Dysplastic diseases of the adnexa: color dilution alopecia and black hair follicular dysplasia. In: GROSS, T.L.; IHRKE, P.J.; WALDER, E.J.; AFFOLTER, V.K. (Eds.). Skin diseases of the dog and cat: clinical and histopathological diagnosis, 2.ed. Oxford: Blackwell Science, 2005. p.518-522.
HARVEY, R.G.; McKEEVER, P.J. Manual colorido de dermatologia do cão e do gato: diagnóstico e tratamento. Rio de Janeiro: Revinter, 2004. 240p.

ISHIDA, Y.; DAVID, V.A.; EIZIRIK, E. et al. A homozygous single base deletion in MLPH causes the dilute coat color phenotype in the domestic cat. Genomics, v.88, p.698-705, 2006.

KIM, J.M.; KANG, K.I.; SOHN, H.J. et al. Color-dilution alopecia in dogs. J. Vet. Sci., v.6, p.259-261, 2005.

LI, W.; SARTELET, A.; TAMMA, N. et al. Reverse genetics screen for loss-of-function mutations uncovers a frameshifting deletion in the melanophilin gene accountable for a distinctive coat color in Belgian Blue cattle. Anim. Genet., v.47, p.110-113, 2015. 
PALUMBO, M.I.P.; FABRIS, V.E.; MACHADO, L.H.A. Carcinoma de células escamosas em um cão com alopecia por diluição de cor. Vet. Zootec., v.19, p.507-512, 2012.

PEREGO, R.; PROVERBIO, D.; ROCCABIANCA, $\mathrm{P}$. et al. Color dilution alopecia in a blue Doberman pinscher crossbreed. Can. Vet. J., v.50, p.511-514, 2009.
VON BOMHARD, W.; MAULDIN, E.A.; SCHMUTZ, S.M. et al. Black hair follicular dysplasia in Large Munsterlander dogs: clinical, histological and ultrastructural features. Vet. Dermatol., v.17, p.182-188, 2006.

WELLE, M.; PHILIPP, U.; RUFENACHT, S. et al. MLPH genotype - melanin phenotype correlation in dilute dogs. J. Hered., v.100, p.S75-S79, 2009. 